\title{
Accounting For Defined Benefit Pension Plans: Is FASB Finally Fulfilling Its 25 Year Old Promise?
}

Brian W. Carpenter, (E-mail: bwc352@scranton.edu), University of Scranton Daniel P. Mahoney, (E-mail: Mahoneyd1@scranton.edu), University of Scranton

\begin{abstract}
With the September 2006 release of Statement No. 158, "Employers' Accounting for Defined Benefit Pension and Other Postretirement Plans," the Financial Accounting Standards Board (FASB) has completed the first phase of its ongoing pension accounting project. The new standard improves the accounting for defined benefit pensions by requiring employers to report the over(under)funded status of their plans as an asset(liability) within the main body of their balance sheet. This requirement represents a significant change from previously-existing pension accounting standards, and represents a major step forward toward the goal of increased transparency in financial reporting. This article provides a discussion of the very lengthy and controversial history of employer pension accounting, and examines the improvements that have finally resulted from Statement No. 158. Also provided is a discussion of the potential outcome of the second and final phase of the FASB's pension accounting project
\end{abstract}

\section{INTRODUCTION}

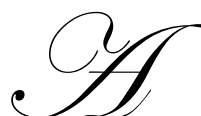

ccounting standards for defined benefit pension plans have long been a source of controversy for the accounting profession. The ideal method of accounting for these pension plans should provide information that is easy for the user to understand and for the preparer to provide. And, of course, the ideal method of accounting for these plans would be based on the most accurate valuations of the pension plan's assets and liabilities. In most cases, the most accurate valuation of pension assets would be based on readily available stock market valuations. The most accurate valuation of the pension liabilities would be based on the best estimate provided by the firms' actuaries. This ideal method of accounting for defined benefit pension plans would be intuitive, easy to understand, and relatively easy to provide. Furthermore, the provisions of such a standard would require nothing more than an adherence to the basic tenets of accounting theory as espoused in the Financial Accounting Standards Board's Conceptual Statements. However, the profession has not used this ideal method of accounting for defined benefit pensions even though variants of it were first proposed nearly 60 years ago.

Interestingly, the reasons for the profession to forgo the use of this ideal method of pension accounting had nothing to do with any of the constructs that are supposed to drive the promulgation of our accounting standards. Instead, the deficiencies in this area of accounting are primarily based on two factors: historical precedence and fear of negative economic consequences. According to the profession's foundational guidance, as found in the Financial Accounting Standards Board's Conceptual Statements, neither of these aforementioned factors should have played any role in the creation of pension accounting standards. Interestingly, and instructively, these factors did play a significant role.

The aforementioned reference to historical precedence refers to the fact that pension accounting was initially based on a "pay as you go" method where pension expense was generally not recognized until actual payment was made to a firm's retirees. The reference to negative economic consequences refers to how the profession feared the negative economic impact that would result from a full recognition of accrued expenses and associated liabilities. Since these large values had not previously been reported, such a move would have caused significant decreases in reported owners' equity of most of the affected firms. 
Given this combination of historical roots in "pay as you go" accounting and the feared economic impact of a change to full accrual accounting, it is easy to understand why the profession was hesitant to mandate a sudden move to fully accrued measures of pension expense and liability. However, such an intuitive understanding of the resulting impasse requires an admission that the promulgation of accounting standards can indeed be affected by factors not found in the profession's professed constructs, as defined in the Concept Statements. Trying to understand the evolution of pension standards without this admission is extraordinarily difficult because it would overlook the primary factors that made the history of pension standards unfold as it did. Overlooking these factors makes the history appear to be disjoint, inconsistent, and illogical. But perhaps most importantly, such a failure to consider these external forces would rob the profession of a unique opportunity to learn from its own history.

The significance of this topic is twofold. First, the controversial nature of the evolution of pension standards provides a uniquely rich opportunity to reflect upon the nature of the accounting standard setting process. Second, the process could possibly be reaching its culmination. The FASB appears to be openly admitting the shortfalls in this important area of accounting and is currently enacting a multi-phase approach that could possibly yield the intuitively understandable and theoretically correct solution that is so long overdue. Truthfully reflecting upon the reasons for the prior impasses will help ensure that this current attempt to solve the problem will more likely achieve its justly deserved successful outcome. To help facilitate this process, this paper discusses the history of accounting for defined benefit pensions, the intuitive reasons for the profession's lengthy impasse in the development of these standards, the perceived deficiencies of the standards in the recent past, and the major requirements and improvements that will result from the FASB's recent standard on this topic.

\section{HISTORY OF DEFINED BENEFIT PENSION ACCOUNTING}

\section{The Committee On Accounting Procedures}

The first notable event in the standard setting history of defined benefit pension plans dates back to 1948 when the Committee on Accounting Procedure issued Accounting Research Bulletin (ARB) No. 36 "Pension Plans: Accounting for Annuity Costs Based on Past Services." At the time of the enactment of ARB 36, pension accounting was typically based on a cash basis approach, which meant that pension expense was primarily a function of payments made to the thencurrent retirees. The Committee on Accounting Procedure correctly observed that this method of accounting failed to properly accrue pension expense and thus focused their attention on resolving this deficiency. The conclusion of their efforts culminated in the issuance of ARB 36. ARB No. 36 recommended that firms allocate their unfunded accumulated benefits over current and future periods in order to better match the "startup" costs of pension plans to the revenues resulting from their employees' labor. Interestingly, the basic premises contained in this initial standard are consistent with the goals currently espoused by the FASB. The primary shortcoming of this initial standard was due to the nature of accounting standard setting at that time, not to any inherent flaw in the standard itself. At that time, the provisions of Accounting Research Bulletins did not have the authoritative backing that is enjoyed by current standards. The provisions of Bulletins were only recommended accounting, meant to persuade and guide accountants. So while ARB 36 generally proposed the conceptually correct ideal of accruing pension expense to better match it with the associated revenues, its lack of authority predictably affected its ability to resolve the pension accounting dilemma.

Nearly ten years lapsed before the Committee on Accounting Procedure revisited this topic in 1956. The Committee's deliberations during that year resulted in the issuance of ARB 47, "Accounting for Costs of Pension Plans". While ARB 36 recommended the accrual of pension expense to provide for better matching, ARB 47 built upon this recommendation by also calling for the recognition of unfunded vested benefits as liabilities on the balance sheet. Thus while ARB 36 primarily focused on the income statement, ARB 47 primarily focused on the balance sheet. The combination of these statements provided recommendations that were again consistent with the ideals that are presently motivating the FASB. These ideals include the need for the full accrual of pension expense and the full recognition of net pension liabilities. 


\section{The Increase In Authority: The Transition From Recommended Accounting To Required Accounting.}

In 1959 the Committee on Accounting Procedures was replaced by the Accounting Principles Board (APB). One of the major differences between the two organizations was the resulting authority of their pronouncements. Accounting Research Bulletins were considered recommended accounting. Conversely, APB Opinions were considered required accounting, and accordingly, had more of an impact on actual accounting practice. The lack of effectiveness of the Committee's previous Bulletins could be evidenced by the fact that until the passage of the APB's Opinion No. 8, nearly all companies continued to use the cash basis to account for their pensions. Apparently, the suggested accounting contained within Bulletins 36 and 47 had little effect on actual accounting practice. The ineffectiveness of proposed accounting standards was one of the main issues that were addressed during the wave of changes that accompanied the creation of the APB. In order to strengthen the authority of the accounting profession's standards, the AICPA and the APB declared that all material departures from Committee Bulletins and APB Opinions had to be disclosed and explained in the companies' published financial statements. The perceived burden of proof and related legal risk that accompanied future departures from these standards effectively brought about the authority that was sought.

Ironically, it could be argued that the profession's ability to enact conceptually correct pension standards was negatively correlated to the standards' resulting authority. When the authority of the standards was weak, as was the case during the reign of the Committee on Accounting Procedures (1939-1959), it was easy to overlook the economic and political consequences of the standard setting process, and to thus enact standards that were driven solely by their conceptual merits. However, when the authority of accounting standards became stronger, as happened subsequent to the creation of the Accounting Principles Board (APB), it became more difficult to overlook the resulting economic and political consequences of the standard setting process. Accordingly, a more thoughtful consideration of the full consequences of this increased authority makes it easier to understand how the resulting pension standards of the APB became less grounded in theory alone. Stated differently, when standards were mere recommendations, they could be driven entirely by theory and without regard to their economic consequences. However, when standards became mandates, adherence to theoretical constructs without due consideration of the economic consequences would have been short-sighted and counterproductive. Thus, the creation of standards by the APB that called for less than full accrual of expenses and less than full recognition of liabilities was more predictable, than it was surprising. It is sheer foolishness to presume that the accounting standard setting process is never affected by perceived economic and political consequences. To say that it is not affected by these consequences is to imply that the profession is indifferent to its societal impact. That is neither the actuality nor the ideal. However, the typical hesitancy to make this admission in a classroom setting makes it needlessly difficult to explain the evolution of, or desired conclusions of, many contemplated accounting standards. This is particularly true of pension accounting standards. The consideration of economic and political effects on the standard setting process provides the perspective that makes the evolution downright logical. Conversely, without this consideration, the theoretical inconsistencies of the evolutionary process make an understanding of it incomprehensible.

\section{The Accounting Principles Board Era}

The Accounting Principles Board was created in 1959 in order to provide increased uniformity and consistency in various areas of financial reporting, including that of pension reporting. The APB's primary contribution to pension accounting came in 1966 when they issued APB Opinion No. 8, "Accounting for the Costs of Pension Plans." If the APB had been motivated to promulgate the most theoretically correct standard possible, they would have called for the full accrual of pension expense and the full recognition of the associated net pension liability. It turned out that APB Opinion No. 8 called for far less than the full accrual of pension expense and for far less than the full recognition of net pension liability. However, its "failure" to do so does not necessarily mean that the APB was acting in a manner that betrayed their societal obligations. In fact, it can be easily argued that an immediate move to full accrual and recognition would have been short-sighted and, consequently, detrimental to the interests of society. By attempting to ease and smooth the transition, as the APB did in Opinion 8, the APB could be seen as providing an intelligent response that balanced the need for improved accounting against the potential for economic harm from moving too fast. With the luxury of hindsight, the need for improved accounting at that time is all too apparent. However, the potential consequences resulting from making those changes too quickly are less obvious. The accumulated pension deferrals of many decades resulted in unrecognized liabilities that exceeded the net worth of many companies. Thus, the immediate recognition of these previously unrecognized liabilities could easily have caused economic consequences severe enough to justify, or even mandate, a 
cautious approach. So while a static analysis of Opinion No. 8 would likely result in criticism for its all too obvious failure to fully accrue pension expense or to recognize the full amount of net pension liability, a more dynamic long term analysis reveals that the provisions of APB 8 fulfilled a predictable and logical need at that time for an incremental step in what was intended to be an evolutionary process.

Accordingly, the primary focus of Opinion No. 8 was on the measurement of periodic pension expense. This focus on expense, rather than liability valuation, allowed the APB to mandate a better valuation of current pension expense (normal cost), while gently nudging the profession to address prior period deferrals. The minimum treatment mandated by the APB was the recognition of interest expense on the accrued deferrals. This treatment served as a cap on previously accumulated deferrals by ensuring these deferred costs would not grow in size due to the mere passage of time. The maximum treatment mandated by the APB required the firms to amortize these accumulated deferrals, which of course would serve to decrease them over time.

APB Opinion No. 8 was important because it provided a clear break with the past practice of basing pension expense solely on cash contributions to the then-current retirees. The ultimate determination of pension expense was based on any of a number of acceptable actuarial cost methods. However, as was previously mentioned, a reasoned decision was made by the APB to not require the full recognition of the net pension liability. Since the majority of these liabilities resulted from the events of prior periods, the APB sought only to encourage the gradual recognition of them through a possible process of amortization.

The main provision of Opinion No. 8 was to provide a range of acceptable expense recognition with the maximum equal to normal cost plus amortization of 10 percent of prior service costs and the minimum equal to normal cost plus interest on prior service cost. Any actuarial method that was consistently used was deemed appropriate as long as the resulting expense was within the aforementioned range. The logic of this treatment of prior period gains or losses can only be fully understood when it is viewed dynamically as an incremental step within an evolutionary process. Accordingly, accounting students, who typically don't view things in either a long-term or dynamic fashion, must have been surprised by statements such the following found in the then-current edition of Kieso and Weygandt's Intermediate Accounting:

The pension liability that frequently appears on company balance sheets represents an accounting credit that results from an excess of amounts expensed over amounts contributed to the pension fund; it does not represent the economic obligations under the plan and usually does not represent amounts legally owed to the pension plan. [page 922, Kieso and Weygandt, Intermediate Accounting, 1980]

Predictably, APB Opinion No. 8 was soon criticized for its shortcomings. However, it remained as the authoritative pension standard for the next 19 years. The most important aspect of Opinion No. 8 was its requirement that normal cost be recognized as a component of pension expense for current and future periods, thus ending the previously predominant practice of equating pension expense with cash payments to a company's then current retirees. However, since the minimum pension expense required by Opinion 8 effectively allowed prior service cost to largely remain off the books, it was remarkable that a standard with such laxity and minimal impact on practice would last as long as it did. On one hand, the creation of a compromised standard at that time was predictable and arguably wise. On the other hand, its longevity was surprising and arguably unwise.

\section{The Financial Accounting Standards Board Era}

The primary FASB standard for defined benefit pensions has long been Statement of Financial Accounting Standard No. 87 "Employers' Accounting for Pensions" which was issued in December, 1985. While there were several other FASB standards issued for pensions, only No. 87 dealt with the fundamental measurement issues affecting the amounts of reported pension expense and net liability. The other myriad statements were largely confined to the topic of footnote disclosure. 
SFAS No. 87 was important in that it brought about a greater standardization of methods used for measuring current pension expense. APB No. 8 allowed the use of any consistently-used actuarial method as long as the resulting expense fell within the APB's allowable range. With SFAS No. 87, the FASB provided specific guidance on the methods to be used to determine pension expense. This newly enacted guidance included the mandatory amortization of prior service cost, a more uniform method of determining how previously deferred actuarial costs would be amortized, and a requirement to recognize a minimum pension liability - albeit under certain highly compromised conditions. Thus, the primary benefit of SFAS No. 87 was that it tightened up the compromises that existed in APB No. 8. The primary deficiency of SFAS No. 87 was that the progress resulting from this enhanced standardization was arguably too meager given the passage of 20 years since the implementation of APB No. 8. However, FASB clearly knew that SFAS No. 87 would not represent the ultimate solution to the pension dilemma. They therefore felt comfortable with the issuance of a standard that represented little more than another step in their anticipated evolutionary process. They emphasized the incremental nature of the statement by offering the following observation:

This statement continues the evolutionary search for more meaningful and more useful pension accounting. The FASB believes that the conclusions it has reached are a worthwhile and significant step in that direction, but it also believes that those conclusions are not likely to be the final step in the evolution. Pension accounting in 1985 is still in a transitional stage. (para no. 5 of SFAS No. 87)

While SFAS No. 87 represented an improvement over APB No. 8, its many compromises mandated the need for additional progress in the future. The fact that it remains as the preeminent standard for pension accounting to this day provides valuable evidence of the strength that external forces can have on the profession's standard setting process. The many FASB standards that followed SFAS No. 87 failed to make any additional changes in the measurement of pension expense. Instead, the pension-related pronouncements that were issued in the 21 year span subsequent to the issuance of SFAS No. 87 were all constrained to issues of disclosure.

It is interesting, predictable, and perhaps disappointing, to observe that the accounting profession reacted to the shortcomings of both APB No. 8 and SFAS No. 87 through the issuance of standards calling for additional footnote disclosure. APB Opinion No. 8 (enacted in 1966) was followed by the disclosure-only Statement of Financial Accounting Standards No. 36, "Disclosure of Pension Information" in 1980. SFAS No. 87 (enacted in 1985) was similarly followed by disclosure-only statements. These post 87 disclosure-only statements included Statement No. 112 issued in 1992, Statement No. 132 issued in 1998, and the revised Statement No. 132 issued in 2003. While the resulting disclosures from these statements might have improved the pension-related information available to financial statement users, it was probably long forgotten that FASB itself had proclaimed that such an approach would never suffice. In Statement 87 (paragraph 116) the FASB included the following interesting observation on this matter:

...footnote disclosure is not an adequate substitute for recognition. The argument that the information is equally useful regardless of how it is presented could be applied to any financial statement element, but the usefulness and integrity of financial statements are impaired by each omission of an element that qualifies for recognition. Further, although the "equal usefulness" argument may be valid for some sophisticated users, the Board does not believe it holds for all or even most other users.

In the end, the requirements of Statement No. 87, like those of Opinion No. 8, represented a compromised approach that could only be applauded if they served as nothing more than an additional incremental step within a responsibly-paced evolutionary process. On the positive side, SFAS No. 87 reigned in the number of options available to financial statement preparers; provided for a more uniform method of determining the amount, if any, of the prior unrecognized gains and losses that would be recognized; required the amortization of prior service costs; and provided for at least some limited consideration of the unfunded obligation as a possible component of pension liability. On the negative side, its compromised provisions yielded a standard that fell far short of the idealized goals of fully accrued expenses on the income statement and accurately valued liabilities on the balance sheet. If Statement 87 was soon after replaced by another statement which pushed the process further along, SFAS 87 could have been viewed as a laudable and valuable step in an evolutionary process. In retrospect, it was the lack of action after 87's implementation that constitutes its primary condemnation. The amount of progress in the provisions of 87 was too small to justify a twenty-one year delay in taking the next substantive step. 
Perhaps Mr. Arthur Wyatt foresaw the likelihood of this outcome when he expressed concerns about the lack of progress represented by SFAS No. 87. Mr. Wyatt, a member of the FASB at that time, noted his dissatisfaction by stating his belief that "...this Statement falls short of achieving the degree of improvement in accounting for pension costs that was attainable and that users of financial statements could justifiably expect from this project." (page 27, SFAS No. 87). He underscored his concern by providing the following dissenting comment in the conclusions of SFAS No. 87:

Mr. Wyatt agrees with the assenters that, on an overall basis, the conclusions in this Statement will lead to improvements in accounting for an understanding of pension costs. He believes, however, that the degree of improvements is modest when related to the improvement that he believes should have been achieved. Thus in his view the Statement's deficiencies represent a lost opportunity for improvement in financial reporting (page 28)

One can only imagine what Mr. Wyatt would have said had he known that there would be no further changes in the measurement of pension expense, or in the balance sheet valuation of net pension liability, for at least 21 years.

\section{CURRENT REGULATIONS AND RECENT FASB ACTIONS}

Regardless of the merits (or lack thereof) of Statement 87, the fact remains that it represents the defining standard for the measurement of pension expense to this day. And until the recent actions by the FASB, it remained as the preeminent standard for the recognition of pension-related assets and liabilities. However, the first phase of the FASB's current pension project has substantively altered this latter fact. While this change might be criticized as being overdue, it possibly foretells a future with additional substantive changes to the remaining artifacts of SFAS No. 87. The evolution, after such a lengthy impasse, has clearly come back to life, and could possibly be nearing its conclusion.

\section{Statement No. 158}

On September $29^{\text {th }}$, 2006, the Financial Accounting Standards Board issued Statement of Financial Accounting No. 158, entitled "Employers' Accounting for Defined Benefit Pension and Other Postretirement Plans". The provisions of this statement represent a significant improvement in the accounting for defined benefit pension plans. The new standard improves current pension accounting by requiring employers to report the overfunded or underfunded status of their defined benefit pension plans as either an asset or liability within the main body of their balance sheet. The fact that meeting such a basic expectation as reporting the plan's funded status is viewed as a significant advance in pension accounting reveals the lack of progress that had been made in this evolution. Until the enactment of this standard, the funded status of defined benefit plans was only required to be disclosed within the firm's footnotes to the financial statements. The mandatory reporting of the net funded status will substantially increase the transparency of defined benefit pension accounting and will enhance the usefulness and understandability of the reported information. But perhaps more importantly, the simple fact that the FASB was willing to venture beyond the safe confines of a disclosure-only mindset seemingly implies a willingness by FASB to touch what has for too long become a metaphorical third rail. The apparent change in mindset is encouraging for those who believe that it is time for the pension "evolution" to yet again focus on financial statement accuracy as the primary goal of pension accounting. While it may be likely that the FASB will attempt to mitigate some of the more negative outcomes associated with a too zealous change in the measurement of pension current pension expense, there is reason to believe that the profession might finally be contemplating making substantive improvements in the measurement techniques that have been 21 years in the waiting.

\section{The Use Of The Projected Benefit Obligation In Measuring The Net Funded Position}

The primary new requirement provided by SFAS No. 158 is for firms to report the net funded status of the pension plan within the main body of the balance sheet. The net funded status of the plan will be measured by comparing the plan's projected benefit obligation to the fair market value of the plan assets. If a firm's net funded status is a liability, this net amount will be equal to the unfunded projected benefit obligation. While SFAS No. 87 required that there be a minimum pension liability reported for any underfunded pension plan, SFAS No. 158's requirement to use the projected benefit obligation is a substantial step forward as it is based on what most accountants (and FASB) believe is the most accurate measure of the pension obligation. The previous value mandated 
by SFAS No. 87 was based on the accumulated benefit obligation. The accumulated benefit obligation does not include the effects of future anticipated pay raises and thus can be argued as being understated. It should be noted that the FASB accomplished this recent improvement without altering any of the main measurement techniques from SFAS No. 87. In effect, they mandated the reporting of the net funded status of pension plans, but left intact the various measurement techniques that were introduced by SFAS No. 87. The changes in the reported net funded status are accomplished via changes in comprehensive income. The most likely perceived deficiency in this approach is that it could be criticized for leaving pension expense unaltered.

\section{Measurement Dates}

SFAS No. 158 also stipulates that the defined benefit plan's assets and obligations that determine a plan's funded status be measured as of the end of the employer's fiscal year. Previously, such measurements were allowed within a span of time that could precede the employer's fiscal year by as much as three months. This provision enhances the usefulness of the reported measures by improving the timeliness of the underlying measures. A limited exception to this requirement is allowed for plans that are sponsored by either a subsidiary or an investee. In these latter cases, the fiscal year of the subsidiary or investee can instead be used.

\section{Comprehensive Income}

The third major requirement of FAS 158 requires that changes in the funded status of defined benefit plans be reported in comprehensive income in the year in which the changes occur. Previously, the net overall effect resulting from changes in a plan's funded status could only be ascertained by reviewing the reconciliations provided within the firm's footnotes.

\section{Effective Dates}

The effective dates of FAS 158's requirements occur in three stages. The requirement to recognize the funded status of the plan becomes effective on December 15, 2006 for entities with publicly traded equity securities. For firms without publicly traded equity securities, this recognition requirement becomes effective as of June 15 , 2007. The requirement to measure the plan's assets and obligations as of the date of the employer's fiscal year-end, becomes effective as of December 15, 2008.

\section{Affected Statements}

FAS 158 amends Statement 87, "Employers' Accounting for Pensions" ; Statement 88, "Employers' Accounting for Settlements and Curtailments of Defined Benefit Pension Plans and for Termination Benefits"; Statement 106, "Employers Accounting for Postretirement Benefits Other Than Pensions", and Statement 132, "Employers' Disclosures about Pensions and Other Postretirement Benefits".

\section{POTENTIAL AREAS OF EXAMINATION IN THE SECOND PHASE}

Statement No. 158 marked the culmination of the first phase of FASB's intended multi-phase approach to improve the accounting for defined benefit pension and other postretirement plans. The statement can be seen as representing a substantive change in both the actual accounting for pensions and the underlying mindset used by FASB. The importance of FASB's departure from disclosure-only pension standards cannot be overstated. As emphasized by FASB itself, disclosure alone cannot resolve the problems inherent in pension accounting. However, it cannot be overlooked that Phase I avoided the contentious issues related to the various mechanics used to actually measure pension expense. Their decision to have periodic changes in net pension assets and/or liabilities reflected in comprehensive income is at once, both laudable and clever. It is laudable because it unquestionably represents a substantive improvement in pension accounting. It is clever because it avoided the truly contentious issue of altering the measurement of pension expense. 
The range of possibilities that could ensue from the next phase of the FASB's pension project is extremely broad. The outcome could possibly range from modest changes in current measurement assumptions to truly watershed changes in pension accounting. At a minimum, the next phase will likely examine issues such as the complex smoothing and amortization processes that still remain as artifacts of SFAS No. 87. Many of these processes represent the compromises made in the days when accounting regulators were still attempting to wean companies from the far weaker requirements of APB Opinion No. 8. The mindset at that time was different from that currently being displayed by the FASB. Accordingly, the forthcoming deliberations will likely involve issues such as the deferral processes used for prior service cost, market volatility, and changes resulting from actuarial corrections. Additionally, it is likely that FASB will at least consider offering additional guidance for the many actuarial assumptions that are part of the current pension measurement procedures. As the balance sheet valuations improve, the variability that ensues from this actuarial latitude will likely become more noticeable and thus more important.

\section{The Preparer Orientation Of SFAS No. 87}

The enactment of SFAS No. 87 in 1986 was, at the time, intended to be little more than an incremental step in a longer evolutionary process. Since SFAS 87 was not intended to be a final statement on pensions, it was by its very nature a compromise. Accordingly, the deliberations that occurred during the development of that standard were relatively unique. Instead of seeking a final end product, FASB was seeking a standard that provided incremental improvement. Due to this environment, FASB was unusually receptive to the desires held by preparers when establishing key provisions of the Standard. Accordingly, the key to understanding the provisions of SFAS No. 87 is to adopt the perspective of the preparer, not the user. If this perspective is adopted, the complexities and compromises of the statement become surprisingly rational and understandable. Most of the complicated measurement mechanisms of SFAS No. 87 are rooted in nothing more mysterious than a natural desire by corporations to mitigate the standard's effect on their resulting financial statements. Stated more directly, pension sponsoring corporations sought to lessen pension-related expense and liability wherever possible. While the accounting profession may be hesitant to admit that it created a standard that favored the interests of the preparer over those of the user, when viewed from a long term perspective, this compromise was surely well-intended and arguably wise.

The importance of SFAS No. 87 to the current discussion of SFAS No. 158 is due to the fact that all of the measurement techniques prescribed within SFAS No. 87 still exist under SFAS 158. In effect, with SFAS No. 158, FASB altered where the numbers are reported without altering how those numbers are derived. Accordingly, an informed analysis of the current pension project requires an understanding of those elements of SFAS 87 that can reasonably be expected to come under review during the second phase of the FASB's pension project.

\section{Will Prior Service Costs, Market Volatilities, And Actuarial Corrections Continue To Be Amortized?}

It should be noted that, at least in theory, FASB could choose to simply discontinue all of the incomesmoothing aspects of SFAS 87 altogether. As FASB itself noted in SFAS No. 87, one of the most theoretically correct measure of pension expense would be based solely on the change in net pension liability:

...it would be conceptually appropriate and preferable to recognize a net pension liability or asset measured as the difference between the projected benefit obligation and plan assets, either with no delay in recognition of gains and losses, or perhaps with gains or losses reported in comprehensive income but not in earnings. (paragraph 107, SFAS No. 87)

If, in the unlikely chance FASB chose to no longer have any "delay in recognition of gains and losses," they would effectively eliminate all the complex mechanisms created by SFAS No. 87 that serve to defer and smooth these various pension-related items. If the FASB decided to take this route, pension expense would ultimately be very similar (or identical) to the pension-related component contained in comprehensive income as mandated by SFAS No. 158. However, it seems highly unlikely that FASB will choose to ignore the arguments previously espoused by preparers regarding their need to defer prior service cost or to defer and amortize the effects of market volatility.

Interestingly, the FASB addressed the possible future outcomes by warning that there should be no conclusions drawn from the mere existence of a second stage: 
The Board expects to readdress in the second phase of the project many issues that were initially addressed in Statements 87 and 106... However, the Board's commitment to readdress those issues and the issues raised by respondents to [SFAS No. 158's] Exposure Draft should not be viewed as a conclusion that the present measurements of defined benefit postretirement obligations are inappropriate or will change. (SFAS No. 158, paragraph B27)

While it appeared as though the FASB was merely warning against prejudging the process, they were more likely demanding their freedom to choose among any potential outcome, including the possibility of making no further changes at all. However, given the fact that this potential outcome was explicitly mentioned, the FASB may have ironically heightened prejudgment rather than mitigate it, by making many readers suspect that an outcome of no changes is now a likely outcome.

Given this set of circumstances, it is probable that FASB is not likely to end the deferral and smoothing mechanisms from SFAS 87. Instead, FASB is much more likely to consider altering these mechanisms in order to further improve their results. Accordingly, an understanding of how SFAS 87 defers and amortizes these various gains and losses will help facilitate an understanding of the likely deliberations that will occur in FASB's second stage of their pension-related process.

\section{Primary Categories Of Deferrals}

There are several elements of SFAS No. 87 that can effectively serve to defer the recognition of pension expense. The three major objectives for allowing these deferrals were to: 1) smooth the effect of valuation changes of pension assets due to market fluctuations, 2) smooth the effect of valuation changes of pension obligations due to actuarial changes, and 3) amortize the effect of newly encountered prior service costs due to pension plan adjustments. The extent to which pension expense is deferred depends, in turn, upon the various thresholds and estimates used during the measurement process. Accordingly, any future examination of these smoothing and deferring techniques is likely to be accompanied by an examination of the associated actuarial estimates and assumptions.

\section{The Deferral Of Market Volatility}

To smooth the effect that market volatility might have on the resulting measure of pension expense, SFAS No. 87 replaces the actual return on plan assets with a firm-derived expected return. Since the amount earned by plan assets helps defray the cost of future pension benefits, these returns reduce pension expense. However, since the stock market is extremely volatile, a direct recognition of this fact could make the resulting pension expense relatively volatile. Quite naturally, firms have a strong distaste for income volatility and would prefer that this linkage between market returns and reported income be subjugated to a smoothing process. SFAS No. 87 satisfied this preference by providing complex mechanisms that, in effect, replace the use of actual returns with expected returns. The differences between the actual returns and the expected returns are deferred for possible future amortization. These differences are referred to as 'asset' gains or losses because they are associated with the pension plan assets. To determine whether these deferred 'excess' returns and/or losses are amortized, they must be: 1) accumulated with the asset deferrals from other periods, 2) added to similar deferrals resulting from unexpected actuarial changes in the value of pension obligations, and 3) compared to a threshold consisting of the larger of 10 percent of the plan's 'market related value' or 10 percent of the "projected benefit obligation".

This resulting smoothing mechanism is so complex that it frequently cannot be understood by even accountants unless they first learn the specific vernacular of pension accounting. For this particular aspect of SFAS No. 87, an understanding of the terms "market related value" and "projected benefit obligation" serves as the necessary vernacular prerequisite. The market related value of the pension plan assets is an average of up to five years of pension plan market values. The projected benefit obligation of a pension plan is an actuarial valuation of the obligation that includes the effect of future estimated pay raises. Only if the accumulated net gain or loss resulting from both market fluctuations and actuarial adjustments exceeds 10 percent of the larger of the market related asset value or projected benefit obligation, is the excess then subject to recognition via amortization. The amount that would be amortized is determined by dividing this excess by the average remaining service life of your workforce. For example, if the accumulated net deferred amount was a loss of $\$ 1,000,000$ and the values for the market related 
asset value and projected benefit obligation were $\$ 700,000$ and $\$ 800,000$ respectively, the excess would be $\$ 200,000$. If the average remaining service life of the workforce was 20 years, the amount of the $\$ 1,000,000$ deferred loss that would be recognized as a part of pension expense would be equal to $\$ 200,000$ divided by 20 , or $\$ 10,000$. The key issue in this analysis is the conceptual tradeoff between the benefits derived from avoiding income volatility versus the negative effect of having pension expense based on a measure that differs from what was actually experienced. In turn, two of the key factors within this issue are: 1) the magnitude of the unrecognized deferrals, and 2) the latitude that preparers have in selecting some of the critical assumptions used in the process. Accordingly, the future pension debate will likely include deliberation of these two aforementioned factors. If it is determined that the unrecognized deferrals are too large, the FASB will likely adjust the thresholds and factors that determine how much expense is deferred and how it is ultimately amortized. Similarly, if the FASB determines that there is too much latitude in the selection of actuarial estimates and assumptions, they will likely examine the guidance in this area in an attempt to enhance the resulting uniformity, comparability, and usefulness of the resulting pension data.

\section{Net Pension Liability Deferral}

As was previously mentioned, deferred pension-related gains and losses are derived from different sources. The primary sources include: 1) the deferral of unexpected gains and losses resulting from market volatility, 2) the deferral of actuarial corrections, and 3) the deferral of prior service cost. The deferral of actuarial corrections is a byproduct resulting from the great number of assumptions that are required to estimate the pension obligation. These assumptions include estimates of inflation rates, salary increases, retiree mortality, and returns on pension plan assets. Obviously, these estimates and assumptions will change over time, affecting, in turn, the resulting estimates of the pension liabilities. The treatment of the resulting change in liability is similar to that used for market volatility. The resulting gains or losses are deferred and accumulated with the other deferrals. This accumulated deferred gain or loss is then compared to the previously discussed threshold to determine if any of it is recognized as a component of future measures of current pension expense. As was previously noted, a related area of possible examination would be the guidance that is available for the selection of these various estimates and assumptions. The latitude in the selection of actuarial assumptions could be seen as an important source of variation, possible lessening the comparability and resulting usefulness of pension date. This would be especially true when inter-company comparisons and analyses are made. Accordingly, it seems probable that the overall area of deferred liability gains and losses is one of the areas that are likely to be discussed during the FASB's second phase of their pension project.

\section{Prior Service Cost Amortization}

The deferral and amortization of prior service cost is probably one of the most interesting aspects of pension cost accounting. Prior service cost arises from the granting of credit for employees' prior service whenever the underlying pension formulation is changed. Let's presume, for example, that an employee has ten years of service and was covered by a pension plan that based annual retirement benefits on the following formula: (years of service x $1 \%$ $\mathrm{x}$ ending annual salary). If the pension plan was altered to increase benefits, there would be an immediate obligation to the employee for his or her prior years of service. For example, if the formula was "sweetened" by increasing the percentage from $1 \%$ to $1.5 \%$, there would be an immediate $50 \%$ increase accrued pension obligation to this employee for his or her prior 10 years of service.

Logical arguments can be made for deferring and amortizing this increment. However, these logical arguments are more strongly based on notions of fair play and desired economic outcomes, rather than accounting theory. Since the increase in prior service cost immediately occurs when the plan is altered, and it is not dependent upon any additional service by the employee, the most natural accounting interpretation of this transaction would be for it to be immediately recognized as an expense. However, a requirement mandating immediate expensing seems contrary to notions of fair play, and would seemingly discourage employers from undertaking actions that society would generally deem to be desirable. The notion of fair play comes into being when you view the transaction from the perspective of the employer. While the employees are not legally obligated to provide any future service to entitle them to the payment of this prior service cost, the employer would not logically have incurred this cost without the expectation of future service from the employees. So, while the legal interpretation of this transaction may indicate that prior service cost is an expense, a more 'common-sensible' interpretation implies that the employer only incurred 
the cost because of the expectation of future services from their workers. Additionally, forcing firms to record the cost as an immediate expense would surely serve as a disincentive for granting such pension enhancements in the future. Accordingly, these factors might have understandably persuaded the accounting profession to be relatively sympathetic to any justifications that employers could offer to legitimize this deferral. Arguably, the methods ultimately chosen to defer and amortize these costs were indeed affected by these non-accounting factors since a dispassionate interpretation of the transaction would have disallowed the current treatment of prior service cost deferral. And perhaps even more revealing is the treatment that is accorded to prior service cost when a plan is deemed to be underfunded. When a sponsoring firm has an unfunded accumulated benefit obligation, the firm is required to recognize additional liability, but is allowed to offset it with an equal intangible asset. In these latter instances, the prior service cost is explicitly recognized as having purchased an asset, even though there is no legal requirement for the employees to provide any additional service to the firm. The deferral and resulting treatment of prior service cost is probably one of the most likely areas that will be examined by the FASB during their forthcoming second stage of their project.

\section{CONCLUSION}

The issuance of SFAS No. 158 by the FASB represents the culmination of the first stage of their planned two stage project on pensions. The results of this first stage are promising in that FASB ventured beyond the confines of the disclosure-only standards that they have issued since the enactment of SFAS No. 87 in 1985. Interestingly, if the goal of the accounting profession were to simply promulgate theoretically correct pension standards, this issue would likely have been resolved at least 40 years ago. However, the topic of pensions is complicated by the interaction of historical precedence and the fear of negative economic consequences. Accordingly, the profession long ago sought to resolve the pension dilemma via an evolutionary process whereby each subsequent standard would push the profession incrementally toward the ultimate goal of fully accrued measures of pension expense and liability. However, human nature predictably intervened in this planned process, causing a twenty-one year stall in the evolution. SFAS No. 158 has restarted this evolution with their two stage pension project. The first stage provides important changes that push the process very close to the long sought goal of fully accrued measures of pension expense and net liability. The largest remaining area of focus relates to the actual measure of current pension expense. SFAS No. 158 avoided this controversial aspect of the topic by limiting their income-related changes to comprehensive income. Accordingly, the remaining possibilities for future FASB deliberation include the measurement of pension expense and the related mechanisms leftover from SFAS No. 87 used to calculate this measure.

The fact that FASB accomplished so much in one step, and did so without altering the contentious measurement techniques from SFAS No. 87, is exceedingly clever and commendable. There is little question that the evolution has taken its next step with SFAS No. 158. Even if no further changes were to be made (which FASB noted as a possibility), the resulting improvements of SFAS No. 158 are significant. The accounting profession and the business world eagerly await the outcome of "Phase II".

\section{REFERENCES}

1. Accounting Principles Board, Accounting for the Cost of Pension Plans, APB Opinion No. 8 American Institute of Certified Public Accountants, 1966.

2. Committee on Accounting Procedure, Accounting for Costs of Pension Plans, Accounting Research Bulletin No. 47 American Institute of Accountants, 1956.

3. Committee on Accounting Procedure, Pension Plans - Accounting for Annuity Costs Based on Past Services, Accounting Research Bulletin No. 36. American Institute of Accountants, 1948.

4. Dyckman, Thomas R., Roland E. Dukes, and Charles J. Davis. Intermediate Accounting $4^{\text {th }}$ edition. Irwin/McGraw-Hill, 1998.

5. Financial Accounting Standards Board, Disclosure of Pension Information, Statement of Financial Accounting Standard No.36 (FASB, 1980).

6. Financial Accounting Standards Board, Elements of Financial Statements of Business Enterprises, Statement of Financial Accounting Concepts No.3 (FASB, 1980). 
7. Financial Accounting Standards Board, Employer's Accounting for Defined Benefit Pension and Other Postretirement Plans - an amendment of FASB Statements No. 87, 88, 106, and 132R, Statement of Financial Accounting Standard No.158 (FASB, 2006).

8. Financial Accounting Standards Board, Employers' Accounting for Pensions, Statement of Financial Accounting Standard No.87 (FASB, 1985).

9. Financial Accounting Standards Board, Employers' Accounting for Postretirement Benefits other than Pensions, Statement of Financial Accounting Standard No.106 (FASB, 1990).

10. Financial Accounting Standards Board, Employers' Accounting for Postemployment Benefits—an amendment of FASB Statements No. 5 and 43, Statement of Financial Accounting Standard No.112 (FASB, 1992).

11. Financial Accounting Standards Board, Employers' Disclosures about Pensions and Other Postretirement Benefits - an amendment of FASB Statements No. 87, 88, and 106, Statement of Financial Accounting Standard No.132 (FASB, 1998).

12. Financial Accounting Standards Board, Employers' Disclosures about Pensions and Other Postretirement Benefits - an amendment of FASB Statements No. 87, 88, and 106, Statement of Financial Accounting Standard No.132R (FASB, 2003).

13. Financial Accounting Standards Board, Objectives of Financial Reporting by Business Enterprises, Statement of Financial Accounting Concepts No.1 (FASB, 1978).

14. Financial Accounting Standards Board, Qualitative Characteristics of Accounting Information, Statement of Financial Accounting Concepts No.2 (FASB, 1980).

15. Financial Accounting Standards Board, Recognition and Measurement in Financial Statements of Business Enterprises, Statement of Financial Accounting Concepts No.5 (FASB, 1984).

16. Kieso, Donald E., Jerry Y. Weygandt and Terry D. Warfield. Intermediate Accounting $11^{\text {th }}$ edition, Volume I. (John Wiley \& Sons, Inc., 2004).

17. Nikolai, Loren A. and John D. Bazley. Intermediate Accounting $7^{\text {th }}$ edition. (South-Western, 1997).

18. Spiceland, J. David, James F. Sepe and Lawrence A. Tomassini. Intermediate Accounting $3^{\text {rd }}$ edition. (McGraw-Hill, 2004). 